\title{
ГЕНДЕРНІ ОСОБЛИВОСТІ СОЦІАЛЬНОЇ КРЕАТИВНОСТІ МАЙБУТНІХ МАГІСТРІВ ПЕДАГОГІЧНИХ СПЕЦІАЛЬНОСТЕЙ
}

\author{
Тетяна Дуткевич \\ кандидат психологічних наук, професор, \\ професор кафедри психології освіти \\ Кам'янець-Подільський національний університет імені Івана Огієнка \\ 32300, Україна, м. Кам'янець-Подільський, вул. Огієнка, 62 \\ tetvik77@gmail.com, http://orcid.org/0000-0003-3792-7195
}

\begin{abstract}
Анотація
У статті розкрито гендерні особливості соціальної креативності майбутніх магістрів педагогічних спеціальностей. Методи дослідження: теоретичні (аналіз та узагальнення результатів психологічних досліджень); емпіричні (методика «Соціальна креативність» А.В. Батаршева); математичної статистики (визначення відсоткових співвідношень, типових результатів варіаційного ряду, середнього квадратичного відхилення, критерію Манна-Уїтні). Виокремлено три підходи до тлумачення соціальної креативності (як феномена міжгрупового порівняння, як одного з видів творчості, як здатності особистості ефективно вирішувати нестандартні ситуації у сфері спілкування і взаємин). Показано, що соціальна креативність педагога є складовою його професійної творчості й професійно важливою якістю, оскільки до його обов'язків належить конструювання навчального (та інших видів) спілкування, залагодження складних і нестандартних комунікативних ситуацій. Встановлено, що більшість майбутніх педагогів має середній і вище рівні соціальної креативності, що дозволятиме їм ефективно виконувати свої професійні функції. Виявлено статистично значущі гендерні відмінності за чотирма 3 вісімнадцяти шкал соціальної креативності. Для хлопців притаманною є більш висока самооцінка своєї рішучості; здатність проявити вимогливість і наполегливість, щоб люди виконали обіцяне; здатність до справ, які оточуючі сприймають як несподівані й принципово нові. Дівчата частіше беруть на себе відповідальність за вирішення найбільш складних проблем і справ. Відповіді й дівчат, й хлопців мають нормальний розподіл, у чоловічій підвибірці вони є більш контрастними, хлопці помітніше відрізняються між собою за проявами соціальної креативності. 3'ясовано, що актуальним завданням у роботі 3 формування соціальної креативності $€$ розвиток здатності майбутніх педагогів трансформувати поставлені цілі й визначені завдання відповідно до умов їхнього досягнення, спроможність доопрацьовувати й вдосконалювати початкові проєкти й задуми у процесі їх втілення.
\end{abstract}

Ключові слова: соціальна креативність, творчість, спілкування, майбутній педагог, гендерні відмінності.

\section{Вступ}

Розбудова нової української школи визначає трансформацію суспільних уявлень про особистість фахівця у галузі освіти, а, відтак ставить чимдалі складніші вимоги до його підготовки. Зокрема, йдеться про спроможність педагогів бути комунікативними лідерами, конструктивно впливати на соціальні процеси у територіальних громадах, забезпечувати 
громадянську злагоду в умовах посилення конкурентних стосунків, притаманних для ринкової економіки. Важливим психологічним чинником вирішення перелічених завдань вбачається соціальна креативність особистості, дослідження якої у майбутніх педагогів набуває виразної актуальності.

В психолого-педагогічних працях знайшли висвітлення проблеми соціальної природи креативності (Amabile, 1983; Chikszentmihalyi, 1988); особливостей комунікативної творчості (Каган \& Эткинд, 1988; Моляко, 1983) і комунікативної креативності (Санникова \& Белоусова, 2001); сутності поняття соціальної креативності (Попель, 2014; Bezouw et al., 2020; Tajfel \& Turner, 1979). Показано, що професійно важливими якостями фахівця у галузі освіти є як комунікабельність (Балл та ін., 2011), так і креативність (Антюхова, 2015; Лазарєв, 2011; Сисоєва, 2014), що поєднуються у феномені соціальної креативності педагога (Саврасов \& Александров, 2019). Однак, поряд із досить значним масивом психолого-педагогічних досліджень із проблеми соціальної креативності спостерігається нестача праць із питань іiі гендерних відмінностей у майбутніх педагогів, що й стало підставою для проведення нашого дослідження.

Мета дослідження: з'ясування шляхом теоретико-емпіричного вивчення гендерних особливостей соціальної креативності майбутніх магістрів педагогічних спеціальностей. Завдання дослідження: 1) розкрити підходи до тлумачення поняття соціальної креативності у сучасній психологічній науці; 2) емпіричним шляхом визначити рівні соціальної креативності досліджуваних; 3) охарактеризувати гендерні відмінності соціальної креативності студентів і визначити їх статистичну значущість.

\section{Методи дослідження}

Теоретичне опрацювання проблеми спиралось на аналіз та узагальнення результатів психологічних досліджень із проблеми соціальної креативності. В емпіричному дослідженні використано методику «Соціальна креативність» (А. В. Батаршев), що складається 318 запитань (шкал), відповідь на кожне з яких передбачає бальну оцінку від 1 до 9. Отримана сума балів дозволяє віднести респондента до одного з рівнів соціальної креативності: дуже низького (18-39 балів), низького (40-54 балів), нижче середнього (55-69 балів), трохи нижче середнього (70-84 балів), середній (85-99 балів), трохи вище середнього (100-114 балів), вище середнього (115-129 балів), високого (130-142 балів), дуже високого (143-162 балів).

3 метою обчислення результатів дослідження використано методи математичної статистики (визначення математичного сподівання, відсоткових співвідношень, типових результатів варіаційного ряду, дисперсії, середнього квадратичного відхилення, критерія Манна-Уїтні).

Досліджувані - студенти педагогічних спеціальностей освітнього ступеня «магістр» (майбутні вчителі української, іноземної мов, фізики, математики, біології, географії, початкових класів) у кількості 156 осіб (48 хлопців і 108 дівчат). Вік досліджуваних 21-24 роки. 3 метою визначення репрезентативності жіночої й чоловічої вибірок використано обчислення математичного сподівання (табл. 1).

Показники математичного сподівання (табл. 1) свідчать про те, що з ймовірністю 0,95 середнє значення при вибірках більшого обсягу не вийде за межі граничної помилки. Отож, жіноча й чоловіча вибірки є достатньо репрезентативними. 
Показники математичного сподівання щодо вибірок досліджуваних

\begin{tabular}{|l|c|c|}
\hline \multicolumn{1}{|c|}{ Показники } & Дівчата, $n=108$ & Хлопиі, $n=48$ \\
\hline $\begin{array}{l}\text { Стандартна помилка вибірки для середнього } \\
\text { арифметичного }\end{array}$ & 1,66 & 1,45 \\
\hline Гранична помилка вибірки & 3,78 & 3,33 \\
\hline Значущість & 0,05 & 0,05 \\
\hline
\end{tabular}

\section{Результати та дискусії}

Аналіз масиву наукових праць засвідчує наявність кількох підходів до тлумачення поняття соціальної креативності особистості. В дослідженнях (Tajfel \& Turner, 1979) феномен соціальної креативності (social creativity) визначено як стратегії, якими люди послуговуються, щоб відновити або підтримати позитивне сприйняття відмінностей між соціальними групами чи категоріями, з якими вони себе ідентифікують. Замість того, щоб за допомогою суспільного змагання підвищити соціальний статус власної групи, люди за допомогою соціальної креативності вдаються до переосмислення, перекручення, чи перевизначення міжгрупових порівнянь, скеровуючи їх на свою користь. При цьому жодних об'єктивних змін у соціальній позиції групи не відбувається. Це більше групова, ніж індивідуальна стратегія, що забезпечує соціальну стабільність.

В психологічному словнику американської асоціації психологів подається близьке за змістом тлумачення соціальної креативності, як «схильності, описаної у теорії соціальної ідентичності, порівнювати власну й інші групи в тих царинах, де власна група $є$ більш успішною, та уникати будь-яких порівнянь у тих сферах, де інші групи є більш успішними» (APA Dictionary of Psychology).

Bezouw et al. (2020), узагальнюючи наукові дослідження, виокремили стратегії соціальної креативності (табл. 2).

Табличя 2

\section{Стратегії соціальної креативності (за Bezouw et al.)}

\begin{tabular}{|l|l|l|}
\hline \multicolumn{1}{|c|}{ Стратегії } & \multicolumn{1}{|c|}{ Типові прийоми } & \multicolumn{1}{|c|}{ Приклади } \\
\hline \multirow{2}{*}{$\begin{array}{l}\text { Зміна критеріїв } \\
\text { порівняння }\end{array}$} & $\begin{array}{l}\text { Применшення значущості } \\
\text { Використання привабливих } \\
\text { ярликів }\end{array}$ & Ми бідні, але нас це не турбує \\
\hline $\begin{array}{l}\text { Акцентування } \\
\text { переваги }\end{array}$ & - & Ми бідні, але щасливі \\
\hline $\begin{array}{l}\text { Порівняння під } \\
\text { новим кутом }\end{array}$ & Порівняння у часі & $\begin{array}{l}\text { Ми бідні, але ми у набагато кращому } \\
\text { стані, ніж десять років тому }\end{array}$ \\
\cline { 2 - 3 } & Порівняння зі стандартом & $\begin{array}{l}\text { Ми бідні, але все одно у кращому } \\
\text { стані, ніж середні європейці }\end{array}$ \\
\hline $\begin{array}{l}\text { Зміна групи для } \\
\text { порівняння }\end{array}$ & Відмінність від подібних груп & Ми менш бідні, ніж інші бідні \\
\cline { 2 - 3 } & Відмінність від більших груп & $\begin{array}{l}\text { Ми бідні, але ми всі - частина цієї } \\
\text { великої країни }\end{array}$ \\
\hline
\end{tabular}

На підставі інших досліджень, соціальну креативність можна розглядати як один з видів творчості. Креативність особистості фокусує процеси перебудови світу із особистісним зростанням її суб'єкта, що є значущим феноменом не лише для суспільства, але й для кожної людини. Це положення дозволяє значно розширити традиційну класифікацію видів творчості 
на наукову, технічну, літературно-художню та доповнити ії такими видами, як музична, образотворча, ігрова, навчальна, побутова («домашня»), військова, управлінська, ситуаційна, комунікативна творчість (Моляко, 1983). Творча організація діяльності людини у різних сферах має місце там, де є домінування пошуків оригінальних, нових рішень традиційних або нестандартних проблем (Моляко, 2007). Так, побутова творчість відіграє важливу роль в особистому житті людини, полягає у вихованні дітей, організації життя у сім’ї (розподіл бюджету, облаштування квартири, приготування їжі тощо). Ситуаційна - передбачає розв'язання задач, що виникають і поза роботою, і поза сім'єю. Наприклад, орієнтування у незнайомому місці, несподівані та екстремальні ситуації в транспорті, на вулиці, під час відпочинку на природі тощо.

Комунікативна творчість виявляється у здатності до побудови (конструювання) різних видів спілкування (ораторського мистецтва, педагогічного й психотерапевтичного спілкування, сімейних або професійних стосунків тощо). Спілкування на творчому рівні передбачає ставлення до співрозмовника як до самостійної цінності, коли обидва учасники $є$ один для одного самостійними цілями (Каган \& Эткинд, 1988). Творче конструювання пронизує всі рівні спілкування: внутрішньо особистісний (внутрішній діалог), міжособистісний і надособистісний (залучення до культурних цінностей). Спілкування у системі «суб'єкт-суб'єкт» призводить до творення духовної спільності «Ми».

На нашу думку, соціальна креативність є особливим видом творчості, який містить місце ознаки ії побутового, ситуаційного й комунікативного видів. Особливим випадком варто вважати діяльність педагога або психолога, що спрямована на розвиток комунікативних якостей дітей, корекцію порушень їх міжособистісних взаємин. Оскільки зазначене належить до обов'язків педагога та психолога, то соціальна креативність може бути визначена також як їхня професійна творчість.

Ще один варіант тлумачення соціальної креативності спирається на здатність особистості ефективно вирішувати нестандартні ситуації у сфері спілкування і взаємин (Попель, 2014; Санникова \& Белоусова, 2001; Саврасов \& Александров, 2019). Типовим для цього підходу є таке тлумачення: «здатність людини оперативно знаходити й ефективно застосовувати нестандартні, оригінальні творчі рішення ситуацій міжособистісної взаємодії. Основою для цілеспрямованого розвитку цієї здатності є система властивостей, що утворюють творчий і комунікативний потенціали особистості» (Попель, 2014: 130).

Відзначено, що соціальна креативність $є$ важливим психологічним чинником професійної діяльності педагога, що виявляється у мовленні (вербально-креативна підсистема), продуктивній взаємодії з людьми, проникливості (соціальна перцепція, емпатія, здатність до моделювання соціальних явищ, розуміння людей); творчій позиції, соціальній активності (соціальний інтерес) (Саврасов \& Александров, 2019).

Важливу роль соціальної креативності підтверджують дослідження процесів профілактики та подолання міжособистісних конфліктів. Доведено, що творчий підхід до аналізу міжособистісних конфліктів є важливим критерієм оцінювання його сформованості у майбутніх педагогів, що забезпечує глибину розуміння сутності конфлікту, оригінальність і продуктивність пропозицій з його подолання. Показниками творчого підходу людини до аналізу конфліктів визначено точність і глибину, оригінальність і продуктивність оцінок і пропозицій, варіативність інтерпретацій чинників конфлікту, запропонованих прогнозів розгортання конфлікту, пропозицій щодо залагодження конфлікту з використанням стратегії співпраці, виграшу обох сторін (Дуткевич, 2021). 
Дослідження соціальної креативності сприяє вирішенню вузлових проблем психології творчості, зокрема, проблеми побудови ефективного спілкування у напружених, критичних, несприятливих ситуаціях (Моляко, 2007). Саме до такої категорії належить низка складних комунікативних ситуацій, що є типовими для педагогічної професії. Прояви творчості у соціальній сфері лише останнім часом стають предметом психологічних досліджень, а, відтак, вивчення гендерних особливостей соціальної креативності майбутніх магістрів педагогічних спеціальностей вбачається актуальним.

Методика «Соціальна креативність» (Батаршев, 2005), що використана в емпіричному дослідженні, відповідає тлумаченню соціальної креативності як здатності особистості ефективно вирішувати нестандартні ситуації у сфері спілкування і взаємин. Отримані результати методики «Соціальна креативність» дозволили визначити розподіл студентів за рівнями соціальної креативності (табл. 3).

Таблиия 3

Розподіл студентів за рівнями соціальної креативності (у \%)

\begin{tabular}{|l|c|c|c|c|c|c|}
\hline Підвибірка & \multicolumn{5}{|c|}{ Рівні соціальної креативності } \\
\cline { 2 - 7 } & $\begin{array}{c}\text { Нижче } \\
\text { середнього }\end{array}$ & $\begin{array}{c}\text { Трохи } \\
\text { нижче } \\
\text { середнього }\end{array}$ & Середній & $\begin{array}{c}\text { Трохи вище } \\
\text { середнього }\end{array}$ & $\begin{array}{c}\text { Вище } \\
\text { середнього }\end{array}$ & Високий \\
\hline Хлопці & - & - & 8,3 & 33,3 & 41,7 & 16,7 \\
\hline Дівчата & 3,7 & 11,1 & - & 40,7 & 37,1 & 7,4 \\
\hline Загалом & 1,8 & 5,6 & 4,1 & 37,0 & 39,4 & 12,1 \\
\hline
\end{tabular}

Як видно 3 табл. 3, переважну частину вибірки віднесено до рівнів трохи вище середнього і вище середнього. В чоловічій підвибірці всі респонденти перебувають на рівнях, починаючи від середнього і вище. Натомість окремі дівчата виявили рівні нижче середнього (3,7\%) і трохи нижче середнього (11,1\%). Порівняно з дівчатами хлопці частіше мають рівні вище середнього (41,7\% на противагу $37,1 \%$ у дівчат) і високий (16,7\% на противагу 7,4\% у дівчат). Відмінності між розподілами дівчат і хлопців за рівнями соціальної креативності статистично незначущі ( $\left.\mathrm{u}_{\mathrm{emp}}=18\right)$, однак спостерігається тенденція до дещо вищого рівня соціальної креативності у чоловічій підвибірці.

Проаналізовано середні значення у вибірках за окремими шкалами (табл. 4).

Таблиия 4

Середні значення (m) за шкалами методики «Соціальна креативність» (у балах)

\begin{tabular}{|c|l|c|c|c|}
\hline $\begin{array}{c}\text { № } \\
\text { 3/ } \\
\Pi\end{array}$ & \multicolumn{1}{|c|}{ Шкали методики } & $\begin{array}{c}\text { Хлопці, } \\
n=48\end{array}$ & $\begin{array}{c}\text { Дівчата, } \\
n=108\end{array}$ & $\begin{array}{c}\text { Загальна } \\
\text { вибірка, } \\
n=156\end{array}$ \\
\hline 1. & $\begin{array}{l}\text { Як часто розпочату справу вам вдається довести до } \\
\text { логічного завершення? }\end{array}$ & 7 & 6,7 & 6,8 \\
\hline 2. & $\begin{array}{l}\text { Якщо всіх людей подумки розділити на логіків і } \\
\text { евристиків, тобто генераторів ідей, то якою мірою Ви } \\
\text { є генератором ідей? }\end{array}$ & 6,4 & 5,5 & 5,8 \\
\hline 3. & Якою мірою ви відносите себе до людей рішучих? & 6,9 & 5,4 & 5,9 \\
\hline
\end{tabular}


Продовження табл. 4

\begin{tabular}{|c|c|c|c|c|}
\hline 4. & $\begin{array}{l}\text { Якою мірою ваш кінцевий «продукт», ваш твір } \\
\text { найчастіше відрізняється від початкового проєкту, } \\
\text { задуму? }\end{array}$ & 4,2 & 5 & 4,7 \\
\hline 5. & $\begin{array}{l}\text { Наскільки ви здатні проявити вимогливість і } \\
\text { наполегливість, щоб люди, які обіцяли вам щось, } \\
\text { виконали обіцяне? }\end{array}$ & 7,8 & 6,7 & 7 \\
\hline 6. & $\begin{array}{l}\text { Як часто вам доводиться виступати } 3 \text { критичними } \\
\text { судженнями на чию-небудь адресу? }\end{array}$ & 5,7 & 5,2 & 5,4 \\
\hline 7. & $\begin{array}{l}\text { Як часто вирішення виникаючих у вас проблем } \\
\text { залежить від вашої енергії та наполегливості? }\end{array}$ & 6,8 & 6,5 & 6,6 \\
\hline 8. & $\begin{array}{l}\text { Який відсоток людей у вашому колективі найчастіше } \\
\text { підтримують вас, ваші ініціативи та пропозиції? } \\
\text { (Один бал - близько } 10 \% \text {.) }\end{array}$ & 5,7 & 5,9 & 5,8 \\
\hline 9. & Як часто у вас буває оптимістичний і веселий настрій? & 7,3 & 6,7 & 6,9 \\
\hline 10. & $\begin{array}{l}\text { Якщо всі проблеми, які вам доводилося вирішувати за } \\
\text { останній рік, умовно розділити на теоретичні та } \\
\text { практичні, то яка серед них питома вага практичних? }\end{array}$ & 6,7 & 6,6 & 6,6 \\
\hline 11. & $\begin{array}{l}\text { Як часто вам доводилося відстоювати свої принципи, } \\
\text { переконання? }\end{array}$ & 6,7 & 6,4 & 6,5 \\
\hline 12. & $\begin{array}{l}\text { Якою мірою ваша товариськість, комунікабельність } \\
\text { сприяє вирішенню життєво важливих для вас } \\
\text { проблем? }\end{array}$ & 7 & 7,1 & 7,1 \\
\hline 13. & $\begin{array}{l}\text { Як часто у вас виникають ситуації, коли головну } \\
\text { відповідальність за вирішення найбільш складних } \\
\text { проблем і справ в колективі вам доводиться брати на } \\
\text { себе? }\end{array}$ & 5,3 & 6,4 & 6,1 \\
\hline 14. & $\begin{array}{l}\text { Як часто і в якій мірі ваші ідеї, проєкти вдавалося } \\
\text { втілювати в життя? }\end{array}$ & 5,5 & 5,7 & 5,7 \\
\hline 15 . & $\begin{array}{l}\text { Як часто вам вдається, проявивши винахідливість або } \\
\text { навіть підприємливість, хоч у чомусь випередити } \\
\text { своїх суперників по роботі чи навчанні? }\end{array}$ & 6,5 & 6,2 & 6,3 \\
\hline 16. & $\begin{array}{l}\text { Як багато серед ваших друзів людей, які вважають вас } \\
\text { людиною вихованою і інтелігентною? }\end{array}$ & 6,7 & 7,1 & 7 \\
\hline 17. & $\begin{array}{l}\text { Як часто вам в житті доводилося робити щось таке, } \\
\text { що було сприйнято навіть вашими друзями як } \\
\text { несподіванка, принципово нова справа? }\end{array}$ & 6,5 & 5,3 & 5,7 \\
\hline 18. & $\begin{array}{l}\text { Як часто вам доводилося докорінно реформувати своє } \\
\text { життя або знаходити принципово нові підходи у } \\
\text { вирішенні старих проблем? }\end{array}$ & 5 & 5,7 & 5,5 \\
\hline 19. & Сума балів & 113,7 & 110,1 & 111,4 \\
\hline
\end{tabular}

Як видно з табл. 4, показники суми балів за всіма шкалами (113,7 у хлопців та 110,1 у дівчат) свідчать, що опитувані, згідно з ключем методики, володіють соціальною креативністю на рівні «трохи вище середнього», якому відповідає діапазон суми балів 110-114.

Хлопцям на високому рівні притаманні такі показники соціальної креативності, як здатність проявити вимогливість і наполегливість, щоб люди, які обіцяли вам щось, виконали обіцяне (7,8 балів) та оптимістичний і веселий настрій (7,3 бали).

На рівні вище середнього у хлопців виражені такі якості соціальної креативності, як: 
здатність доводити розпочату справу до логічного завершення $(7,0)$; самооцінка своєї рішучості $(6,9)$; розуміння залежності вирішення проблем, виникаючих від власної енергії та наполегливості $(6,8)$; переважання серед усіх вирішених проблем практичних $(6,7)$; частота відстоювання своїх принципів, переконань $(6,7)$; міра, якою товариськість, комунікабельність респондента сприяє вирішенню його життєво важливих проблем $(7,0)$; вдале випередження своїх суперників за рахунок винахідливості й підприємливості $(6,5)$; кількість знайомих, які вважають респондента людиною вихованою і інтелігентною $(6,7)$; частота справ респондента, які інші сприймають як несподівані, принципово нові $(6,5)$.

Натомість трохи нижче середнього у хлопців виражена міра, якою кінцевий «продукт» відрізняється від початкового проєкту, задуму $(4,2)$. Тобто, хлопці є більш цілеспрямованими у досягненні своїх задумів й, водночас, менш гнучкими в ситуаціях, коли свій задум під впливом різноманітних перешкод потрібно коригувати.

У дівчат на рівні вище середнього виявляються такі показники соціальної креативності: здатність доводити розпочату справу до логічного завершення $(6,7)$; здатність проявити вимогливість і наполегливість, щоб люди, які обіцяли вам щось, виконали обіцяне $(6,7)$; розуміння залежності вирішення виникаючих від власної енергії та наполегливості $(6,5)$; оптимістичний і веселий настрій $(6,7)$; переважання серед усіх вирішених проблем практичних $(6,6)$; міра, якою товариськість, комунікабельність респондента сприяє вирішенню його життєво важливих проблем $(7,1)$; кількість знайомих, які вважають респондента людиною вихованою і інтелігентною $(7,1)$.

Решта показників соціальної креативності дівчат мають середній i трохи вище середнього рівні й перебувають у діапазоні від 5 до 6,4 балів.

Максимально вираженими у хлопців $є$ здатність проявити вимогливість i наполегливість, щоб люди виконали обіцяне (7,8 балів) та оптимістичний і веселий настрій (7,3 бали). В дівчат максимальних балів (по 7,1) досягає міра, якою їхня товариськість i комунікабельність сприяють вирішенню життєво важливих проблем, і кількість знайомих, які вважають їх вихованими й інтелігентними.

Відмінність між хлопцями і дівчатами в 1 бал і більше спостерігається за такими показниками, як: самооцінка своєї рішучості $\left(\mathrm{m}_{\text {хл }}=6,9, \mathrm{~m}_{\text {дів }}=5,4\right) ;$ здатність проявити вимогливість і наполегливість, щоб люди виконали обіцяне $\left(\mathrm{m}_{\mathrm{xл}}=7,8, \mathrm{~m}_{\text {дів }}=6,7\right)$; частота ситуацій, якщо відповідальність за вирішення найбільш складних проблем і справ у колективі доводиться брати на себе $\left(\mathrm{m}_{\mathrm{xл}}=5,3, \mathrm{~m}_{\text {дів }}=6,4\right)$; частота справ респондента, що сприймаються іншими як несподівані, принципово нові $\left(\mathrm{m}_{\mathrm{xл}}=6,5, \mathrm{~m}_{\text {дів}}=5,3\right)$. Відмінності за цими чотирма шкалами є значущими 3 ймовірністю 0,05 (критерій Манна-Уїтні $\mathrm{u}_{\mathrm{emp}}=4,5$ ). Отримані дані свідчать про те, що для хлопців притаманною є більш висока самооцінка своєї рішучості, порівняно з дівчатами; здатність проявити вимогливість і наполегливість, щоб люди виконали обіцяне; здатність до справ, що сприймаються іншими як несподівані й принципово нові. Натомість дівчата частіше беруть на себе відповідальність за вирішення найбільш складних проблем і справ у колективі.

Найнижчу оцінку отримано у дівчат (5) і у хлопців $(4,2)$ за шкалою міри, в якій кінцевий «продукт» відрізняється від початкового проєкту, задуму. Можна передбачати, що здатність трансформувати поставлені цілі й визначені задуми відповідно до умов їх досягнення $\epsilon$ найбільш актуальним завданням для формування соціальної креативності майбутніх педагогів.

За сукупністю шкал методики «Соціальна креативність» не виявлено суттєвої різниці 
між хлопцями і дівчатами ( $\mathrm{u}_{\mathrm{emp}}=129$, незначущий), однак спостерігається тенденція до дещо вищого рівня соціальної креативності у хлопців за одинадцятьма 3 вісімнадцяти шкал методики.

Наступним кроком був проведений аналіз варіаційних рядів, утворених середніми балами за кожну шкалу (питання) методики «Соціальна креативність» (табл. 5).

Таблиия 5

Показники варіаційних рядів за шкалами методики «Соціальна креативність» гендерних підвибірках студентів

\begin{tabular}{|l|c|c|c|c|c|}
\hline \multicolumn{1}{|c|}{ Підвибірка } & $m$ & $M o$ & $M e$ & $D$ & $\sigma$ \\
\hline Хлопці & 6,31 & 6,7 & 6,6 & 0,78 & 0,88 \\
\hline Дівчата & 6,12 & 6,7 & 6,3 & 0,42 & 0,64 \\
\hline Загальна вибірка & 6,18 & - & 6,2 & 0,43 & 0,65 \\
\hline
\end{tabular}

Варіаційні ряди хлопців і дівчат мають однакові моди $(\mathrm{Mo}=6,7)$. Решта показників різняться. У хлопців вищими $\epsilon$ : середнє значення ( $m=6,31$ бал на противагу 6,12 у дівчат); медіана (Me=6,6 на противагу 6,3 у дівчат); дисперсія $(D=0,78$ на противагу 0,42 у дівчат) та середнє квадратичне відхилення ( $\sigma=0,88$ на противагу 0,64 у дівчат). Відповіді дівчат і хлопців мають нормальний розподіл, однак у хлопців вони є більш контрастними, помітніше відрізняються між собою за проявами соціальної креативності. Критерій Манна-Уїтні $\left(\mathrm{u}_{\mathrm{emp}}=8,5\right)$ свідчить, що відмінності у показниках варіаційних рядів, утворених відповідями хлопців і дівчат, є статистично значущими $(0,05)$.

\section{Висновки}

Внаслідок теоретичного вивчення досліджуваної проблеми виокремлено три підходи до тлумачення соціальної креативності у психології: 1) як феномена міжгрупового порівняння, що забезпечує особистості задоволення власним соціальним статусом і статусом своєї соціальної групи; 2) як виду творчості, що виявляється у здатності до побудови різних видів спілкування; 3) як здатності особистості ефективно вирішувати нестандартні ситуації у сфері спілкування і взаємин. Встановлено, що соціальна креативність педагога - складова його професійної творчості, професійно важлива якість, адже його обов'язками є й конструювання різних видів спілкування (зокрема, навчального), вирішення складних і нестандартних комунікативних ситуацій.

За даними емпіричного дослідження, більша частина майбутніх педагогів має середній і вище рівні соціальної креативності, що дозволятиме їм у майбутньому ефективно виконувати свої професійні функції.

Відмінності між розподілами дівчат і хлопців за рівнями соціальної креативності статистично незначущі. Однак спостерігається тенденція до дещо вищого рівня соціальної креативності у чоловічій підвибірці. Водночас, окремі дівчата виявили рівні нижче середнього і трохи нижче середнього.

Статистично значущі гендерні відмінності визначено за чотирма шкалами соціальної креативності. Хлопцям притаманна більш висока самооцінка своєї рішучості; здатність проявити вимогливість і наполегливість, щоб люди виконали обіцяне; здатність до справ, які інші сприймають як несподівані й принципово нові. Дівчата частіше беруть на себе відповідальність за вирішення найбільш складних проблем і справ у колективі. На противагу 
дівчатам, хлопці помітніше відрізняються між собою за проявами соціальної креативності.

Актуальним завданням у роботі $з$ формування соціальної креативності $є$ розвиток здатності майбутніх педагогів трансформувати поставлені цілі й визначені завдання, згідно умов їх досягнення, спроможність доопрацьовувати і вдосконалювати початкові проєкти i задуми у процесі їх втілення.

Перспективи подальших досліджень стосуються виявлення таких психологічних чинників соціальної креативності, що пов'язані з формуванням компетентності командної роботи (конфліктність, здатність до співпраці, толерантність тощо) у майбутніх педагогів.

\section{Література}

1. Антюхова, Н.I. (2015). Концептуальна модель творчого потенціалу майбутнього вчителя іноземних мов. Гуманітарний вісник ДВНЗ «Переяслав-Хмельницький державний педагогічний університет імені Григорія Сковороди». Тематичний випуск «Міжнародні Челпанівські психолого-педагогічні читання», 7-14.

2. Балл, Г.О., Зливков, В.Л., Копилов, С.О., Курганська, Л.О., \& Михайлюк, Л.М. (2011). Педагогічна комунікащія та ідентичність педагога. (Монографія). Київ : Педагогічна думка.

3. Батаршев, А.В. (2005). Базовые психологические свойства и профессиональное самоопределение личности: Практическое руководство по психологической диагностике. Санкт-Петербург : Речь.

4. Дуткевич, Т.В. (2021). Психологія конфліктності студентів педагогічних спеціальностей. (Монографія). Київ : КНТ.

5. Каган, М.С., \& Эткинд, А.М. (1988). Общение как ценность и как творчество. Bonpocbl психологии, 4, 25-34.

6. Лазарєв, М.О. (2011). Творчість як родова властивість людини і основа педагогічної діяльності. А.А. Сбруєва, О.В. Єременко, \& О.В. Михайличенко (Ред.). Педагогічні науки: теорія, історія, інноваційні технології, 3(13), 93-105.

7. Моляко, В.А. (1983). Психология решения школьниками творческих задач. Киев : Радянська школа.

8. Моляко, В.А. (2007). Творческая конструктология (пролегомены). Киев : «Освита Украины».

9. Попель, А.А. (2014). Социальная креативность: новые подходы к конструированию понятия. Вестник Нижегородского университета имени Н.И. Лобачевского. Социальные науки, 3(35), 129-135.

10. Саврасов, М., \& Александров, К. (2019). Соціальна креативність у структурі творчих здібностей майбутнього педагога. Професіоналізм педагога: теоретичні ц̆ методичні аспекти, 9, 105-115.

11. Санникова, О.П., \& Белоусова, Р.В. (2001). Оценка показателей коммуникативной креативности с помощью оригинальной методики. Наука і освіта, 6, 52-54.

12. Сисоєва, С.О. (2014). Творчий розвиток фахівців в умовах магістратури. (Монографія). Київ : Едельвейс.

13. Amabile, T.M. (1983). The social psychology of creativity. New York : Springer-Verlag.

14. APA Dictionary of Psychology. Electronic resource. Access mode: https://dictionary.apa.org/social-creativity

15. Chikszentmihalyi, M. (1988). Society, culture and person: A system view of creativity. In R. Sternberg \& T. Tardif (Eds.), The nature of creativity. (pp. 325-339). Cambridge : Cambridge Press. 
16. Maarten Johannes van Bezouw, Jojanneke van der Toorn, \& Julia Christina Becker (2020). Social creativity: Reviving a social identity approach to social stability. European Journal of Social Psychology, 1-14. https://doi.org/10.1002/ejsp.2732

17. Tajfel, H., \& Turner, J.C. (1979). An integrative theory of intergroup conflict. In W.G.Austin \& S.Worchel. (Eds.), The social psychology of intergroup relations. (pp. 33-47). Brooks/Cole.

\section{Referenses}

1. Antiukhova, N.I. (2015). Kontseptualna model tvorchoho potentsialu maibutnoho vchytelia inozemnykh mov [Conceptual model of foreign language future teacher's creative potential]. Humanitarnyi visnyk DVNZ "Pereiaslav-Khmelnytskyi derzhavnyi pedahohichnyi universytet imeni Hryhoriia Skovorody”. Tematychnyi vypusk "Mizhnarodni Chelpanivski psykholohopedahohichni chytannia", 7-14 [in Ukrainian].

2. Ball, H.O., Zlyvkov, V.L., Kopylov, S.O., Kurhanska, L.O. \& Mykhailiuk, L.M. (2011). Pedahohichna komunikatsiia ta identychnist pedahoha [Pedagogical communication and teacher's identity]. Kyiv : Pedahohichna dumka [in Ukrainian].

3. Batarshev, A.V. (2005). Bazovye psykholohycheskye svoistva y professyonalnoe samoopredelenye lychnosty: Praktycheskoe rukovodstvo po psykholohycheskoi dyahnostyke [Basic psychological properties and professional self-determination: A practical guide to psychological diagnosis]. Saint Petersburg : Rech, 208 [in Russian].

4. Dutkevych, T.V. (2021). Psykholohiia konfliktnosti studentiv pedahohichnykh spetsialnostei [Psychology of conflict at pedagogical specialties students]. Kyiv : KNT, 240 [in Ukrainian].

5. Kahan, M.S., \& Эtkynd, A.M. (1988). Obshchenye kak tsennost y kak tvorchestvo [Communication as a value and as creativity]. Voprosy psykholohyy - Psychology issues, 4, 2534 [in Russian].

6. Lazariev, M.O. (2011). Tvorchist yak rodova vlastyvist liudyny i osnova pedahohichnoi diialnosti [Creativity as a human generic attribute and the basis of pedagogical activity]. In: A.A. Sbruieva, O.V. Yeremenko, \& O.V. Mykhailychenko et al. (Eds.). Pedahohichni nauky: teoriia, istoriia, innovatsiini tekhnolohii - Pedagogical sciences: theory, history, innovative technologies, 3(13), 93-105 [in Ukrainian].

7. Moliako, V.A. (1983). Psykholohyia reshenyia shkolnykamy tvorcheskykh zadach [Psychology of schoolchildren's creative problems solving]. Kyiv : Radianska shkola [in Ukrainian].

8. Moliako, V.A. (2007). Tvorcheskaia konstruktolohyia (prolehomeny) [Creative constructology (prolegomenos)]. Kyiv : "Osvita Ukrainy” [in Ukrainian].

9. Popel, A.A. (2014). Sotsyalnaia kreatyvnost: novye podkhody k konstruyrovanyiu poniatyia [Social creativity: new approaches to concept construction]. Vestnyk Nyzhehorodskoho unyversyteta imeni N.Y. Lobachevskoho. Sotsyalnye nauky - Bulletin of the Nizhny Novgorod University named after N.I. Lobachevsky. Social sciencies, 3(35), 129-135 [in Russian].

10. Savrasov, M., \& Aleksandrov, K. (2019). Sotsialna kreatyvnist u strukturi tvorchykh zdibnostei maibutnoho pedahoha [Social creativity in the structure of creative abilities of the future teacher]. Profesionalizm pedahoha: teoretychni y metodychni aspekty - Teacher professionalism: theoretical and methodological aspects, 9, 105-115 [in Ukrainian].

11. Sannykova, O.P., \& Belousova, R.V. (2001). Otsenka pokazatelei kommunykatyvnoi kreatyvnosty $\mathrm{s}$ pomoshchiu oryhynalnoi metodyky [Communicative creativity indicators evaluation by original methodology using]. Nauka i osvita - Science and education, 6, 52-54 [in Russian].

12. Sysoieva, S.O. (2014). Tvorchyi rozvytok fakhivtsiv v umovakh mahistratury [Specialists' creative development in the conditions of a magistracy]. Kyiv : Edelveis [in Ukrainian].

13. Amabile, T.M. (1983). The social psychology of creativity. New York : Springer-Verlag. 
14. APA Dictionary of Psychology. Electronic resource. Access mode: https://dictionary.apa.org/social-creativity

15. Chikszentmihalyi, M. (1988). Society, culture and person: A system view of creativity. The nature of creativity. In R. Sternberg \& T. Tardif (Eds.). (pp. 325-339). Cambridge : Cambridge Press.

16. Maarten Johannes van Bezouw, Jojanneke van der Toorn, \& Julia Christina Becker (2020). Social creativity: Reviving a social identity approach to social stability. European Journal of Social Psychology, 1-14. https://doi.org/10.1002/ejsp.2732

17. Tajfel, H., \& Turner, J.C. (1979). An integrative theory of intergroup conflict. The social psychology of intergroup relations. In W.G.Austin \& S.Worchel (Eds.), (pp. 33-47) Brooks/Cole.

\title{
GENDER FEATURES OF SOCIAL CREATIVITY AT FUTURE MASTERS OF PEDAGOGICAL SPECIALTIES
}

Tetiana Dutkevich

PhD in Psychology, Professor, Professor of the Department of Psychology of Education

Kamianets-Podilskyi National Ivan Ohiienko University

62, Ohiienko Str., Kamianets-Podilskyi, Ukraine, 32300

tetvik77@gmail.com, http://orcid.org/0000-0003-3792-7195

\begin{abstract}
The article reveals the social creativity gender features at future masters of pedagogical specialties. Research methods: theoretical (analysis and generalization of psychological studies results); empirical (method "Social Creativity" by Batarshev); mathematical statistics (determination of percentages, typical results of the variation series, variance, standard deviation, Mann-Whitney test). It was described three approaches to social creativity interpretation (as a phenomenon of intergroup comparison, as one of the types of creativity, as person's ability to effectively construction of nonstandard communicative situations). It was shown that teacher's social creativity is a component of his (her) professional creativity, a professionally important quality, because pedagogue's competence includes the construction of educational (and other types of) communication, the settlement of nonstandard communicative situations. It was established that most future teachers have average and higher levels of social creativity, which will allow them to perform their professional functions effectively. Statistically significant gender differences were identified on four of the eighteen scales of social creativity. Boys have a higher self-esteem of their resoluteness; the ability to demand and persist in order to people keep their promises; ability to do things that others perceive as unexpected and absolutely new. Girls are more likely to take responsibility for solving the most difficult problems and cases. The answers of both girls and boys have a normal distribution, in the mens' subsample they are more contrasting, boys differ deeper in their social creativity manifestations. It was found that the most important task in future teachers' social creativity formation is the development of their ability to transform goals and objectives accordingly with its achievement conditions, the ability to refine and improve initial projects and ideas in the process of its implementation.
\end{abstract}

Keywords: social creativity, creativity, communication, future teacher, gender differences. 